\title{
COMPARATIVE ANALYSIS OF PADDY AND OIL PALM FARM INCOME IN TANJUNG JABUNG TIMUR REGENCY
}

\author{
Junita Purba*), Dompak Napitupulu*), and Yusma Damayanti*) \\ *) Department of Agribusiness, Jambi University \\ Jl. Raya Jambi - Muara Bulian, KM.15 Mendalo Indah, Muaro Jambi, Jambi, Indonesia
}

\begin{abstract}
This research aims to analyze the cost and net income of wetland paddy and palm oil smallholder farming in Tanjung Jabung Timur Regency. The subjects of this research were rice and oil palm smallholder farmers particularly palm oil farmers who were recorded to perform functional shift of land use such as from rice to palm oil. The primary data obtained through interviews with rice and oil palm smallholder farmers in research areas, and secondary data collected from various offices and related agencies. Data analyzes used quantitative descriptive methods. The results showed that net income of oil palm farming was significantly greater than net income of rice farming per ha per year. A lower income from rice farming activity was caused by a higher production cost due to higher labor costs compared to oil palm farming.
\end{abstract}

Keywords: farm management, rice farming, oil palm, cost, farm income

\begin{abstract}
Abstrak: Penelitian ini ditujukan untuk membandingkan struktur biaya dan penerimaan petani dari usahatani padi sawah dan kelapa sawit rakyat di Kabupaten Tanjung Jabung Timur. Subyek dari penelitian ini adalah petani kelapa sawit khususnya yang mengalihfungsikan lahan sawah menjadi usahatani kelapa sawit. Data dalam penelitian ini terdiri dari data primer yang dikumpulkan dengan metode survey dari responden petani dan data sekunder yang diperoleh dri instansi terkait. Data dianalisis dengan metode kuantitatif. Hasil analisis data menunjukkan bahwa pendapatan usahatani kelapa sawit secara nyata lebih tinggi dari pendapatan usahatani padi sawah per hektar per tahun. Pendapatan usahatani padi sawah yang secara nyata lebih rendah dari pendapatan usahatani kelapa sawit disebabkan oleh biaya usahatani padi yang lebih tinggi dari usahatani kelapa sawit yang utamanya disebabkan oleh biaya tenaga kerja usahatani padi sawah yang lebih tinggi dibandingkan usahatani kelapa sawit.
\end{abstract}

Kata kunci: usahatani, padi sawah, kelapa sawit, biaya, pendapatan

\footnotetext{
${ }^{1}$ Corresponding author:

Email: dompakn@unja.ac.id
} 


\section{INTRODUCTION}

Agricultural sector is important in Indonesian economic development. This sector contributes $13.34 \%$ to Nasional Income (based on the current market price in 2014), second after the processing industry sector (BPS, 2017). In 2016, 22.54\% of Indonesians earned income from agriculture sector. Nevertheless, it is an important issue to manage sustainable agricultural business due to uncontrolled population growth and lack of arable land and water (Widadie and Agustono, 2016; Herrero et al. 2010). Moreover, the arable land needed efficient agricultural practice (Lemaire et al. 2013). Therefore, to increase welfare, efficient farming can be done by focusing on high yield agricultural commodities such as oil palm and rice. Rice is a prime commodity as the main source of staple food and, farmers choose tocultivate paddy on the farms (Soekartawi, 2002). In addition, rice demand is higher than the production, since Indonesia imported rice from other countries. BPS (2017) reported that Indonesia imported 256.56 thousand tons of rice during January-October 2017 with a value of US \$ 119.78 million.

Indonesia Government with its programs maintains rice farming as the main food crop, however, the introduction of oil palm cultivation was able to shift land use for food production including paddy fields. The functional shift of food production area to other uses in Tanjung Jabung Timur Regency was very rapid., The rice farming decreased from 32,453 ha in 2011 to 20,569 ha in 2014 or an average by $12.20 \%$ per year (BPS, 2015).

The functional shift of land use in Tanjung Jabung Timur Regency was anticipated by the regulation Number 18 of 2013 on Sustainable Agricultural Land Farm Protection (PLP2B). The regulation prohibits farmers to convert their farm production area to other uses. However, the offered profit incentives in oil palm farming motivated some farmers to disobey the regulation. The rapid change of land use from paddy field to oil palm plantation encouraged a research on the income comparison between paddy farming and palm oil farming in Tanjung Jabung Timur Regency (Daulay et al. 2016). The research problem was the income difference between paddy farming and palm oil farming that influence functional shift on land use in Tanjung Jabung Timur Regency? The study objective was to analyze the cost and net income of rice and palm oil smallholder farming in Tanjung Jabung Timur Regency.

Due to the lack of domestic rice of production Indonesia imported rice from other countries, however. Some paddy farm areas were converted to oil palm plantation, including in Tanjung Jabung Timur regency. Local government anticipated by drafting local regulation, however it success was limited. Some rice farmers chosed to change their farming area to grow oil palm. This research reveals the farmers' economic reason to change their land use from paddy-to other plantations via farm income analyzes approach.

This research aimed to analyze the cost and net income per year of paddy and palm oil smallholder farming in Tanjung Jabung Timur Regency. The subjects of this research were rice and oil palm smallholder farmers particularly those who convert their land use from paddy to oil palm.

\section{METHODS}

This research analyzed the farmers' income that received from paddy and oil palm farming. The research studied the cost of production incurred by farmers and the reasons of farmers decision to shift from rice farming into oil palm plantation business. This research was conducted in Tanjung Jabung Timur Regency. The location was chosen purposively to find farmers who were converted their paddy field into palm oil plantation. The research was conducted from September to October 2017.

Primary data collected from survey that used a set of questions that was previously validated. The secondary data collected from various offices and related agencies. The quantitative descriptive method calculated the cost and net income per year of paddy and palm oil small-holder farming based on revenue and production cost in a one-year period. Farm income defined as the difference between the amount of revenue and costs incurred. The revenue was the amount of production multiplied by the selling price which reduced by the costs incurred in the production process. Revenue formula is as follows (Soekartawi, 1995): 


$$
\mathrm{TR}=\mathrm{P} \times \mathrm{Q}
$$

Where: TR (Total Revenue in IDR $(\mathrm{Rp} / \mathrm{Ha})$ ); $\mathrm{P}$ (Production Price in IDR (Rp/Kg)); Q (Quantity (Kg/ Ha))

Total cost was calculated by the sum of fix cost and variable cost that paid during production process in both rice and oil palm farms as follows: (Soekartawi, 1995).

$$
\mathrm{TC}=\mathrm{FC}+\mathrm{VC}
$$

where: TC(Total Cost in IDR (Rp/Ha)); FC (Fixed Cost in IDR (Rp/Ha)); VC (Variable Cost in IDR (Rp/Ha)).

Farmers' income was calculated by subtracting the total revenue by the total farm expenditures in both paddy and oil palm respectively as follows:

$$
\mathrm{FI}=\mathrm{TR}-\mathrm{TC}
$$

Where: FI (Farmer Income (Rp/Ha/Year)); TR (Farm Total Revenue (Rp/Ha/Year)); TC (Farm Total Cost $(\mathrm{Rp} / \mathrm{Ha} /$ Year $)$ ).

The income difference between paddy and oil palm farms was analyzed by t-test two-sample test with statistical hypothesis:

$\mathrm{H} 0: \mu 1=\mu 2$

$\mathrm{H} 1: \mu 1 \neq \mu 2$

Where: $\mu 1$ (rice farm income average); $\mu 2$ (oil palm farm income average). The value of t-test used formula:

$$
t=\frac{\bar{Y}_{1}-\bar{Y}_{2}}{\sqrt{\frac{s_{1}^{2}}{n_{1}}+\frac{s_{2}^{2}}{n_{2}}}}
$$

Where: Y1 (rice farm average income); Y2 (oil palm smallholder average income); $\mathrm{n} 1$ (rice farm sample number); $\mathrm{n} 2$ (oil palm smallholder sample number); $\mathrm{s}_{1}{ }^{2}$ (rise farm income variance); $\mathrm{s}_{2}{ }_{2}$ (oil palm smallholder income variance).

Income variances was calculated by the formula:

$$
S^{2}=\frac{\sum\left(Y-\bar{Y}^{2}\right.}{n-1}
$$

The rule was if $\mathrm{t}_{\text {stat }}>\mathrm{t}_{\text {table }}, \mathrm{H}_{0}$ is rejected means that $\mu_{1}$ is not equal to $\mu_{2}$, otherwise, $H_{0}$ is accepted means that the average income of those type of farm are similar each other.

\section{RESULT}

The main indicator of productive firm was a benefit that gained from the production process. In this research, benefit was counted by farmers' income. Based on that definition, it is important to calculate the total revenue received by both types of farming.

The findings showed that the average total revenue of rice farming ( $\mathrm{Rp} 26,537,398.37 / \mathrm{Ha} / \mathrm{Year}$ ) was higher than the total revenue from oil palm farming (Rp22,216,239.46/Ha/Year). The farmers' total revenue between these types of farming were significantly different from each other ( $\mathrm{t}$-stat was 3.47 higher than t-table with $\mathrm{df}=70$ and $\alpha=0.01$ i.e. equal to 2.38) Average revenue of paddy field per hectare per year was significantly higher than average revenue of oil palm plantation per hectare per year from. Table 1 presents The distribution of farmers' revenue between the two types of farming.

The rice farmer's total revenue ranged from $\mathrm{Rp} 8,500,000$ to Rp34,500,000 per hectare per year with an average of Rp24,547,390.98 per hectare per year (Table 1). On the other hand, the palm oil farmer's total revenue ranged from $\mathrm{Rp} 11,750,001$ to $\mathrm{Rp} 31,250,000$ per hectare per year with an average revenue of Rp22,216,239.46 per hectare per year. The finding indicates that rice farming had greater incentives than palm oil farming. The rice farmers converted their land use into oil may be caused by the cost difference of both farming. While other farmers' motive was to get more leisure time. Since oil palm farming used less labor-intensive.

Rice farm costs per hectare per year was higher than oil palm on the same farm size. Rice farm cost ranged from $\mathrm{Rp} 4,634,500$ to $\mathrm{Rp} 19,628,000$ per hectare per year with and average of Rp13,374,089.02 (Table 2). The oil palm cost ranged from Rp3,405,437.50 to Rp10,458,750 with an average of Rp6,094,567.21. The oil palm cost in this area was found to have a lower cost than farmers in Simalungun North Sumatera that reached Rp11,486,004 per hectare per year (Nathalia et al. 2013). 
Figure 1 shows that the largest cost component of rice farming was labor cost $(62.06 \%$ of total production cost per hectare). It is almost similar to the finding in previous study in Mauro Jambi Regency (Siregar et al. 2018). While the largest cost component of oil palm farming was for fertilizer which reaches $38.09 \%$.
The amount of labor cost in rice farming $\mathrm{i}$ indicates an intensive activity on rice farming compared with oil palm farming. The labor-intensive in rice farming was the main factor that caused all $(100 \%)$ farmers to convert their land use into palm oil farming.

Table 1. Rice and oil palm farmer distribution based on total revenue gained from their farm business in Tanjung Jabung Timur Regency in 2017

\begin{tabular}{ccc}
\hline Interval of Revenue $(\mathrm{Rp} / \mathrm{Ha})$ & Rice Farm $(\%)$ & Oil Palm Smallholder $(\%)$ \\
\hline $8,500,000-11,750,000$ & 7.32 & 0.00 \\
$11,750,001-15,000,000$ & 0.00 & 2.86 \\
$15,000,001-18,250,000$ & 0.00 & 20.00 \\
$18,250,001-21,500,000$ & 4.88 & 17.14 \\
$21,500,001-24,750,000$ & 24.39 & 31.43 \\
$24,750,001-28,000,000$ & 21.95 & 20.00 \\
$28,000,001-31,250,000$ & 4.88 & 8.57 \\
$31,250,001-34,500,000$ & 36.59 & 0.00 \\
\hline
\end{tabular}

Table 1. Rice and Oil Palm farmer distribution based on total cost spend on their farm business in Tanjung Jabung Timur Regency, Rp/Ha, Year 2017

\begin{tabular}{|c|c|c|}
\hline Interval of Total Cost $\quad(\mathrm{Rp} / \mathrm{Ha})$ & Rice Farm (\%) & Oil Palm Smallholder (\%) \\
\hline $3,405,437.50-5,433,257.81$ & 2.44 & 42.86 \\
\hline $5,433,257.82-7,461,078.13$ & 4.88 & 37.14 \\
\hline $7,461,078.14-9,488,898.44$ & 9.76 & 14.29 \\
\hline $9,488,898.45-11,516,718.75$ & 9.76 & 5.71 \\
\hline $11,516,718.76-13,544,539.06$ & 21.95 & 0.00 \\
\hline $13,544,539.07-15,572,359.38$ & 26.83 & 0.00 \\
\hline $15,572,359.39-17,600,179.69$ & 9.76 & 0.00 \\
\hline $17,600,179.70-19,628,000.00$ & 14.63 & 0.00 \\
\hline
\end{tabular}

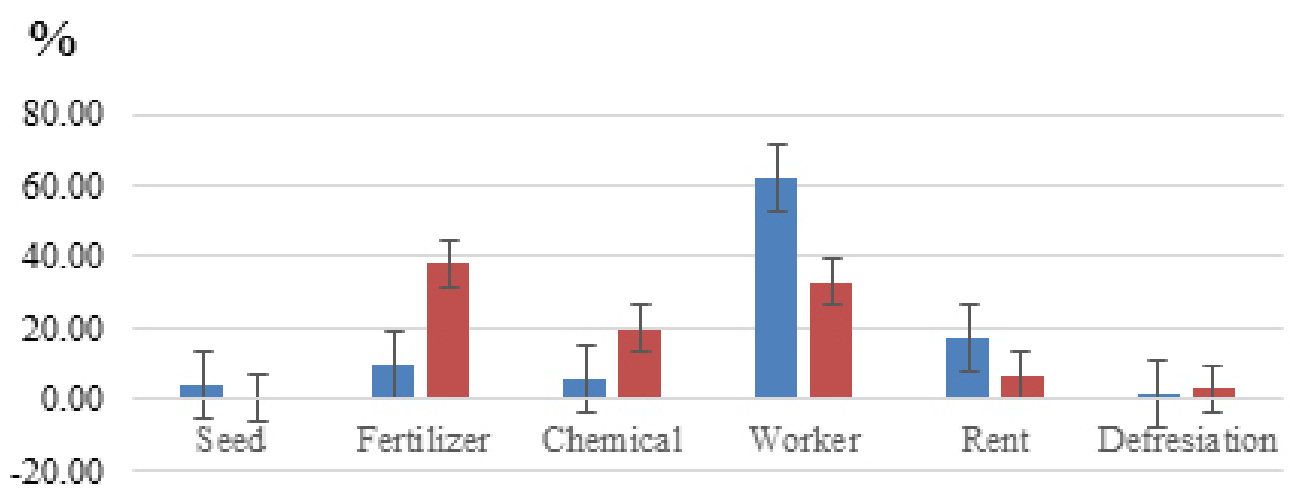

$$
\text { " Rice " oil Palm }
$$

Figure 1. Input cost paid by rice and oil palm farmer per hectare in 2017 
Other researchers found that oil palm plantation used less intensive labor. Yulistriani and Mahdi (2017) found that palm oil smallholder used 84.5 working days $/$ ha/ year which means less than 0.25 labor per hectare per day. The high technology used in oil palm production process caused this efficiency. The type of work activities were limited to fertilizing and weeding in oil palm that performed mechanically. On the other hand, rice farming at the maintenance stage was performed manually (Swardana et al. 2013). The labor cost that impacts on the total income of rice was higher compared to the income of foil palm farmer. The benefit from rice and oil palm farming are shown in Table 3.

The benefit gained by oil palm farmer was higher than what rice farmer. Around $37.14 \%$ oil palm farmer made a net benefit that ranged from Rp15,209,953.14 to $\mathrm{Rp} 17,825,343.75$ per hectare per year, while around $36.59 \%$ rice farmers made $\mathrm{Rp} 12,594,562.51$ to Rp15,209,953.13 per hectare per year. Armin (2017) found that oil palm plantation tends to offer greater potential to generate higher income per hectare compared to other annual crops. A higher-income was due to oil palm plantation efficiency in production inputs usage, especially in labor.

The highest net income interval to the rice farmer was $\mathrm{Rp} 17,825,343.76$ to $\mathrm{Rp} 20,440,734.38$ (Figure 2). It is lower than the net income gained by oil palm farmer, which was Rp20,440,734.39-23,056,125. on average, rice farmer made real net income around Rp13,163,309.35 per hectare per year, which was lower than oil palm grower who made around Rp16,121,672.24. The rice farm net-income in Tanjung Jabung Timur District was found two times higher than the rice farm in Tanjung Jabung Barat Regency, (Rp6,116,135.613 per hectare per production process or approximately Rp12,232,271.2 per hectare per year) (Nur-Oetama et al. 2013). Andriani (2016) said that although farmer earned sufficient income from oil palm farming they will perform rice farming as a side farm income source if they have time.

Table 3. Rice and oil Palm farmer distribution based on Net Income gained from their farm business in Tanjung Jabung Timur Regency, Year 2017.

\begin{tabular}{ccccc}
\hline $\begin{array}{c}\text { Interval of Income } \\
(\mathrm{Rp} / \mathrm{Ha} / \text { Year })\end{array}$ & \multicolumn{2}{c}{ Rice Farm } & \multicolumn{3}{c}{ Oil Palm } \\
\cline { 2 - 5 } & Frequency (farmer) & Percentage (\%) & Frequency (farmer) & Percentage (\%) \\
\hline $2,133,000.00-4,748,390.63$ & 3 & 7.32 & 0 & 0.00 \\
$4,748,390.64-7,363,781.25$ & 1 & 2.44 & 0 & 0.00 \\
$7,363,781.26-9,979,171.88$ & 4 & 9.76 & 0 & 0.00 \\
$9,979,171.89-12,594,562.50$ & 5 & 12.20 & 7 & 20.00 \\
$12,594,562.51-15,209,953.13$ & 15 & 36.59 & 5 & 14.29 \\
$15,209,953.14-17,825,343.75$ & 9 & 21.95 & 13 & 37.14 \\
$17,825,343.76-20,440,734.38$ & 4 & 9.76 & 8 & 22.86 \\
$20,440,734.39-23,056,125.00$ & 0 & 0.00 & 2 & 5.71 \\
Total & 41 & 100.00 & 35 & 100.0 \\
\hline
\end{tabular}

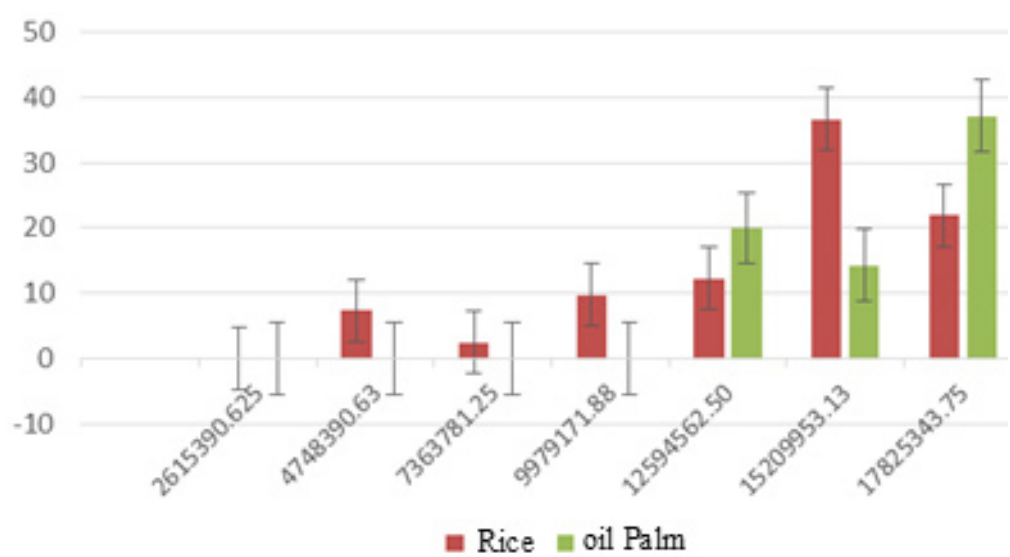

Figure 2. Farmer distribution based on benefit gained from their farm business in 2017 
The net income gained by oil palm farmers in Tanjung Jabung Timur District was higher than oil palm farmers in Tanjung Jabung Barat (Rp6,562,666) but lower than oil farm farmers in Labuhan Batu District North Sumatera (Ritonga, 2008; Posma et al. 2016). Therefore they converted they land usage from paddy to oil palm, this similar finding was found in some village areas in North Sumatera (Ilham, 2016)

The statistical analysis of "t-test two sample" showed the value of t-stat of 3.71 was greater than the value of t table: 2.38 (with $\alpha=0.01$ and d.f. 70). The result found that the income of both types of farming was different from the value of "zero" or in other words the income per hectare per year from the oil palm farming was greater than the income that can be obtained from rice farming.

The findings show the lower net income of rice farming compared to palm oil farming was caused by the higher production cost in the same size of planting area. By assuming income as the main motivation to do farming, the effort to protect the functional shift of land use area for staple food production should be attained by the efficiency of labor cost and usage. Therefore, a new technology introduction such as mechanization to replace labor in rice farming of agriculture in the research location should be considered as one of the efforts to protect the number of paddy field area and rice production in Tanjung Jabung Timur Regency.

\section{Managerial Implications}

One merit finding of this research is that oil palm farm is potentially more profitable than the wet rice farm. That significant net income was due to the more efficient input specially labor used in oil palm planted by smallholder. In addition, oil palm also has a very wide range of both land physic and climate adaptability that make it potentially replace wet rice farm. Some farmer without too much consideration divert their rice field function into oil palm plantation area. That is probably not too big problem especially if we count in from the individual farmer house hold economy side of view, but from the rice farm culture itself it could cost big problem by losing rice farm from the people culture. Local food self sufficiency of course be the first sign and has to be paid serious attention from local government.

\section{CONCLUSIONS AND RECOMMENDATIONS}

\section{Conclusions}

The results showed that net income of oil palm farming was greater than net income of rice farming per ha per year in Tanjung Jabung Timur Regency. The low income of rice farming relative to the income of palm oil farming was caused by the production cost of rice farming. The higher cost of rice farming was caused by the labor cost. In general, the study indicated that rice farming required intensive labor usage than the palm oil. The intensive labor usage made the total cost became higher and the net income became lower.

\section{Recommendations}

This research finding lead the author to kindly suggest the local government to pay attention to keep wet rice farming become lost from the rural people culture. This can be done by food commodity impartial policies impartial policies in the form of subsidized prices of inputs as well as commodities, introducing appropriate technology that can reduce labor cost. Another policy need to keep rice farmer to keep farmers working on their paddy fields with the support of farm road infrastructure so as to facilitate farmers in marketing their agricultural product.

\section{REFERENCES}

Andriani E. 2016. Analisis sumber pendapatan petani kelapa sawit. AGRISEP 16(2): 145 - 154. https:// doi.org/10.31186/jagrisep.16.2.145-154.

Armin. 2017. Studi tingkat pendapatan petani sebelum dan sesudah konversi lahan pertanian ke perkebunan kelapa sawit di Desa Pakawa Kecamatan Pasangkayu Kabupaten Mamuju Utara. e Jurnal Katalogis 5(3): 100-108.

BPS. 2015. Kabupaten Tanjung Jabung Timur Dalam Angka. Jambi: Badan Pusat Statistik Provinsi Jambi.

BPS. 2017. Ekonomi Indonesia Tahun 2016. Jakarta: BPS.

Daulay AR, Eka IKP, Baba B, Bambang PN. 2016. Analisis faktor penyebab alih fungsi lahan sawah menjadi sawit di Kabupaten Tanjung Jabung Timur. Analisis Kebijakan Pertanian 14(1):1-15. https://doi.org/10.21082/akp.v14n1.2016.1-15. 
Herrero M et al. 2010. Smart investments in sustainable food production: revisiting mixed cro p-livestock systems. Science 327(5967):822-5.

Ilham M. 2016. Analisis komparatif pendapatan petani sebelum dan sesudah beralih ke komoditi kelapa sawit di Desa Ujung Rambe Kecamatan Bangun Purba Kabupaten Deli Serdang [minithesis]. Medan:Universitas Sumatera Utara.

Lemaire G, Alan F, Paulo CFC, Benoît D. 2013. Toward agricultural sustainability through integrated crop-livestock systems: environmental outcomes. Agriculture, Ecosystems and Environment 190: 1-3. https://doi.org/10.1016/j. agee.2014.04.028.

Nathalia S, Kesuma S, Sinar I. 2013. Analisis komparasi tingkat pendapatan usaha tani karet rakyat dengan usaha tani kelapa sawit rakyat Di Desa Buntu Bayu Kecamatan Hatonduhan Kabupaten Simalungun. Journal of Agriculture and Agribusiness Socioeconomics 2(10): 1-15.

Nur-Oetama DS, Emy K, Arnoldy A. 2013. Analisis usahatani padi sawah dan usahatani kedelai di Kecamatan Berbak Kabupaten Tanjung Jabung Timur. Jurnal Ilmiah Sosio-Ekonomika Bisnis 16(2):95-104. https://doi.org/10.22437/jiseb. v16i2.2785.

Posma A, Eliza, Suardi T. 2016. Palm Farmers Income Distribution Patterns In The Village Rimpian Swadaya Lubuk Batu Jaya District Indragiri Hulu Regency. Jurnal Online Mahasiswa (JOM)
Fakultas Pertanian (FAPERTA) Universitas Riau 3(2):1-9.

Ritonga D. 2008. Analisis komparasi usahatani antar komoditas kakao, kelapa sawit, dan karet. Studi Kasus Desa Gunung Slamet, Kecamatan Bilah Hulu, Kabupaten Labuhan Batu [minithesis]. Medan:Universitas Sumatera Utara.

Siregar PA, Damayanti Y, Nainggolan S. 2018. Analisis komparasi pendapatan usahatani padi, jagung, kedelai di Kecamatan Kumpeh Kabupaten Muaro Jambi. Jambi: Universitas Jambi.

Soekartawi. 2002. Analisis Usaha Tani. Universitas Indonesia Pers. Jakarta.

Suardana P. A., Made A., Nur Alam M. 2013. Analysis of production and income rice farming the pattern Legowo In Laantula Jaya Village Of Witaponda Discrict Morowali Regency. Agrotekbis 1(5): 477-484.

Yulistriani and Mahdi. 2017. Profil, allocation, and labor income on palm oil smallholders in Solok Selatan District. AGRISEP 16(1): 25 - 32. https:// doi.org/10.31186/jagrisep.16.1.25-32.

Widadie F, Agustono A. 2016 Comparison of integrated crop-livestock and non-integrated farming systems for financial feasibility, technical efficiency and adoption (Case of farmers in Gunung Kidul regency, Yogyakarta, Indonesia). Journal of the International Society for Southeast Asian Agricultural Sciences 21(1):31-45. 